\title{
Serial defaults, serial profits: Returns to sovereign lending in Habsburg Spain, 1566-1600
}

\author{
Mauricio Drelichman ${ }^{\mathrm{a}, \mathrm{b}, *}$, Hans-Joachim Voth ${ }^{\mathrm{c}, \mathrm{d}}$ \\ ${ }^{a}$ The University of British Columbia, Canada \\ b CIFAR, Canada \\ ${ }^{c}$ ICREA/Universitat Pompeu Fabra, Spain \\ ${ }^{\mathrm{d}}$ CREI, Spain
}

\section{A R T I C L E I N F O}

\section{Article history:}

Received 1 April 2010

Available online 18 October 2010

\section{JEL classification:}

N23

F34

G12

\section{Keywords:}

Sovereign debt

Serial default

Rate of return

Profitability

Spain

\begin{abstract}
A B S T R A C T
Philip II of Spain accumulated debts equivalent to $60 \%$ of GDP. He also defaulted four times on his short-term loans, thus becoming the first serial defaulter in history. Contrary to a common view in the literature, we show that lending to the king was profitable even under worst-case scenario assumptions. Lenders maintained long-term relationships with the crown. Losses sustained during defaults were more than compensated by profits in normal times. Defaults were not catastrophic events. In effect, short-term lending acted as an insurance mechanism, allowing the king to reduce his payments in harsh times in exchange for paying a premium in tranquil periods.
\end{abstract}

(c) 2010 Elsevier Inc. All rights reserved.

\section{Introduction}

Sovereign lending is a risky business. From its earliest days, lenders put their fate into the hands of princes. Many lost capital, property, and some, their lives. Payment stops, defaults, and outright repudiations have been common since individuals and banks started lending to sovereigns. A select group of states have failed to honor their obligations multiple times, earning the moniker of 'serial defaulters' (Reinhart et al., 2003).

Why cross-border lending occurs at all is puzzling. By definition, there is no third-party enforcement of the creditor's rights. Explanations have emphasized the role of reputation (Eaton and Gersovitz, 1981; Eaton and Fernandez, 1995; Tomz, 2007), sanctions (Bulow and Rogoff, 1989; Mitchener and Weidenmier, 2010; Conklin, 1998), and debt as an implicit contingent claim in incomplete markets (Grossman and Van Huyck, 1988; Yue, 2010; Kovrijnykh and Szentes, 2007; Arellano, 2008). Despite the many difficulties in making countries pay, sovereign lending on average has been profitable since 1850 . Restructurings were common in the 19th and 20th century, but bondholders still earned respectable returns ex-post (Eichengreen and Portes, 1989; Lindert and Morton, 1989). Sovereign borrowing may therefore be sustainable because 'Tis better to have lent and lost than never to have lent at all' (Wallich, 1943).

Why lenders should offer funds to countries with a distinguished history of serial default is less clear. Reinhart et al. (2003) argue that countries can become 'debt intolerant'. Once a default has occurred, future defaults become more likely. ${ }^{1}$ Defaults cause

\footnotetext{
* Corresponding author. The University of British Columbia, Canada.

E-mail address: drelichm@interchange.ubc.ca (M. Drelichman).

1 Kohlscheen (2007) argues that governance structures matter, with presidential democracies more likely to become serial defaulters than parliamentary ones. His model can extended to explain how less constrained monarchies have a higher chance of becoming serial defaulters.
} 
a progressive weakening of the borrowing country's fiscal system. Some borrowers have remarkable records: Venezuela has defaulted nine times since 1824, followed by Mexico's eight, and Brazil's seven. Bank lending to such borrowers is difficult to rationalize since a nation's repayment history is public knowledge. Defaults cannot come as a surprise. Reinhart and Rogoff (2009) argue that lending to repeat offenders occurs in waves, and is driven by a search for yield at a time when developed country bonds only offer low interest rates. As such, changes in investor sentiment could be important contributors to boom-and-bust cycles in bond markets (Baker and Wurgler, 2007; Barberis et al., 1998). ${ }^{2}$

We examine the first serial defaults in history - the bankruptcies of Philip II of Spain (1556-98). During his reign, payments to creditors were suspended four times. ${ }^{3}$ Over the following centuries, Spain (including its predecessor state, the Kingdom of Castile) went on to renege on its debts 13 times, making it the world-record holder. Philip II's lenders have long been considered prime examples of irrational exuberance. Historians since Braudel (1966) have argued that bankers engaged in lemming-like behavior, lending to the king in repeated waves of excessive optimism. We use a dataset of 435 original loan contracts from the Archive of Simancas to examine lending to the Castilian Crown in the sixteenth century.

In this paper, we calculate the cash flow for each short-term debt contract of Philip II's reign. Bankers obtained healthy profits by maintaining a long-term lending relationship with the Crown. This result takes into account the bankruptcies and the restructurings that occurred in the normal course of business. This finding is robust to a wide variety of alternative assumptions. The bankruptcies did not affect the cost of borrowing. This is consistent with the interpretation that defaults were largely anticipated (and already priced-in) by the lenders. Ex-post rates of return - after deducting the 'haircuts' negotiated in the settlements - were proportional to the seriousness of the liquidity crisis that prompted each default. Short-term lending thus functioned as insurance. The king paid a premium in normal times, but could 'cash in' by not servicing his debts and reducing the outstanding principal when times were hard.

Our findings allow us to reject the sentiment hypothesis. We show that long-term financial relationships between the Crown and its bankers delivered substantial mutual benefits. These findings suggest that even serial defaults need not be cataclysmic events for bankers. For the lenders to Philip II, profits and repeated defaults were not mutually exclusive. Settlements were negotiated quickly and offered generous terms, at least by 19th and 20th century standards. Lending resumed promptly; bankers anticipated that losses from the bankruptcies would be offset by profits.

We are not the first to study sixteenth-century asientos. Carande (1987) examined the loans of Charles V, while Ulloa (1977) compiled an overview of Philip's borrowing. Our classification, coding, and elaboration, however, go further than anything attempted so far. First, we take advantage of the reorganization of documents at the Archive of Simancas to capture the entire population of asientos. Second, we eliminate all instances of double counting present in Ulloa's work. ${ }^{4}$ Crucially, we are the first to examine the contract clauses themselves, instead of the brief summaries on the first page. In this way, estimated returns fully reflect the complexity of loan contracts.

This research forms part of a larger project on the debts and fiscal position of sixteenth-century Castile. Elsewhere, we show that Philip II's finances were in good order, and that his debts were sustainable. The bankruptcies reflected liquidity crises rather than solvency problems (Drelichman and Voth, 2010). ${ }^{5}$ Bankers lent in overlapping syndicates, effectively forming a lenders' coalition. This prevented the king from defaulting opportunistically, and ensured repayment whenever sufficient funds were available (Drelichman and Voth, 2011). ${ }^{6}$

We proceed as follows. Section 2 gives a short historical background and introduces the borrowing instruments used by the Crown of Castile. Section 3 describes our data and discusses our assumptions and conventions. Section 4 presents our main results. Section 5 provides some additional discussion, and Section 6 concludes.

\section{Historical background}

Philip II ruled between 1556 and 1598. In addition to modern-day Spain's territory, he inherited Northern Catalonia, ${ }^{7}$ the Low Countries, Naples and Sicily, the Franche-Comté, the Duchy of Milan, several North-African outposts, and the American colonies (the 'Indies'). He further acquired the Philippines in 1571 and Portugal and its empire in 1580. While Philip ruled many territories, the Kingdom of Castile provided most revenues. Through the marriage of Isabella and Ferdinand in 1469, Castile had gained the right to all future colonial acquisitions. This came to include the Indies and their rich silver mines. Silver would become one of the most important sources of revenue for Philip II, accounting for a quarter of Crown income by the late 16th century. ${ }^{8}$ Taxes and

\footnotetext{
${ }^{2}$ A theory of individually rational sentiment shift unrelated to fundamentals is provided by Bénabou (2009). Recent theoretical work has sought to rationalize endogenous shifts in bond market sentiment as a result of investment managers signaling skills (Guerrieri and Kondor, 20010).

3 Philip II only defaulted on short-term loans; long-dated bonds were serviced throughout his reign (with the exception of bonds issued as collateral for shortterm loans).

${ }^{4}$ Double counting arose when a field commander entered into a loan directly with a banker, and sent the document to Madrid to be ratified. The central treasury would re-issue the loan, or consolidate it into a larger one. Both documents were kept in the series. The only way of matching them and eliminate duplicates is to read the relevant clauses.

5 We also compare Castile's fiscal performance to that of other leading European powers in Drelichman and Voth (2010).

6 Conklin (1998) and Alvarez Nogal (2003) offer alternative interpretations of the incentives that made lending possible.

7 It was ceded to France in the Treaty of the Pyrenees (1659).

8 See Drelichman and Voth (2010) for a reconstruction of every Castilian revenue stream on an annual basis for the years 1556 to 1596 . Other relevant works on sixteenth-century Castilian fiscality include Ruiz Martín (1965), Ulloa (1977), Artola (1982), Thompson (1994a,b), Gelabert (1999), Yun Casalilla (2002, 2004), Sanz Ayán (2004), Marcos Martín (2000), and De Carlos Morales (2008).
} 
Table 1

Stock, service and cost of long-term debt (in millions of current ducats).

\begin{tabular}{|c|c|c|c|c|}
\hline Year & Outstanding Juros & Juros servicing cost & Average cost of Juro service & Revenue \\
\hline 1560 & 19 & 1.468 & $7.7 \%$ & 3.155 \\
\hline 1565 & 25 & & & 4.192 \\
\hline 1566 & & 1.861 & $7.4 \%^{\mathrm{a}}$ & 4.770 \\
\hline 1573 & & 2.752 & & 5.433 \\
\hline 1575 & 42.5 & 2.730 & $6.4 \%$ & 7.606 \\
\hline 1584 & & 3.273 & & 7.806 \\
\hline 1598 & 68 & 4.634 & $6.8 \%$ & $11.328^{\mathrm{b}}$ \\
\hline
\end{tabular}

Source: debt estimates for 1560, 1565 and 1598 are from Artola (1982); the figure for 1575 is from De Carlos Morales (2008). Service estimates are from Ruiz Martín (1965) and Ulloa (1977). Revenues are from Drelichman and Voth (2010).

a Calculated using 1565 stock of juros.

b Figure from 1596.

silver revenues funded Philip's bid for supremacy. This involved the king in almost continuous wars. Philip II's empire was at peace for only a single year of his reign (Parker, 1998).

War was expensive. Military spending accounted for more than 90\% of Crown expenditure. Castile relied heavily on borrowing to smooth the fluctuations in revenues and to be able to increase expenditure when necessary. Philip II used both long- and shortterm debt, in the form of instruments known as juros and asientos.

\subsection{Juros}

Long-term bonds were called juros. These were either perpetuities or, less commonly, lifetime annuities. They varied in terms of face value and interest rate. They were backed by specific tax streams. Payments were collected directly from the tax administrators. The Cortes - the representative assembly of Castile - had the prerogative of designating which tax streams could be used to back long-term bonds. This placed an effective ceiling on juro issuance, making them one of the safest investments available. ${ }^{9}$ Juros were widely held by institutions and individuals in Castile and the rest of Europe, and were never defaulted upon in the sixteenth century. While their stock grew during our period of analysis, our knowledge of their specific dynamics is imperfect. The archival record is essentially intractable, and only summary estimates exist for specific years. ${ }^{10}$ Table 1 provides an overview.

Long-term debt grew in parallel with royal revenue. ${ }^{11}$ Most juros carried an interest rate of $7.14 \%$, and were sold at par. This is the rate we use in later calculations. In addition to standard issuance, bankers received large tranches of juros during the settlements with the Crown in 1577 and 1597. These carried an interest rate of 5\%. As Table 1 shows, the average cost of juro borrowing therefore fell in the late 16 th century.

\subsection{Asientos}

Juros could only be issued against revenue that the Cortes designated as 'ordinary'. Between 1555 and 1596, ordinary revenues averaged only $55 \%$ of total income and, crucially, did not include silver. The king used short-term debt contracts called asientos to borrow against other revenues. Asientos had been introduced by Charles V, Philip's father. ${ }^{12}$ Within one year of acceding to the throne, Philip II stopped servicing these debts. A short-lived plan to restart lending did not prosper, and a second payment stop was declared in 1560. The first two defaults of Philip's reign were eventually resolved with a deal brokered by Genoese banking families. Short-term lending restarted in earnest in 1566.

The Genoese introduced several innovations in asiento contracts. The most important one was collateralization with long-term bonds. Collateral clauses gave bankers the right to hold juros until the loan was discharged in full, and to sell them in case it was not. At the end of a contract, bankers could often keep the collateral in lieu of payment. This made the Genoese large intermediaries in the juro market. ${ }^{13}$ Controlling both long and short-term debt gave bankers substantial leverage when negotiating with the king. ${ }^{14}$

\footnotetext{
9 The ceiling was raised only a few times in the 16th century. The relationship between the Crown and the Cortes has been the subject of extensive study. Some representative treatments are Carretero Zamora (1988), Jago (1981, 1985), Thompson (1976, 1993, 1994a,b), Fortea Pérez (2009), and the proceedings of the Congreso Científico sobre la Historia de las Cortes de Castilla y León (Las Cortes de Castilla y León en la Edad Moderna, 1989).

${ }^{10}$ While the National Historical Archive and the Archive of Simancas hold thousands of juros, no central registry exists. Only a small fraction is catalogued, and bonds are only identified by the name of the first holder. This makes it impossible to search them by date, tax stream, location or any other useful characteristic. Finally, only bonds that ever changed hands (and hence had to be re-issued) are preserved in the archives, imparting a serious bias to the documentary record. These difficulties explain the sparse literature on juros, with the most comprehensive overview provided by Toboso Sánchez (1987).

11 All our statements on the evolution of Castile's fiscal position are based on Drelichman and Voth (2010).

12 The standard reference on the asientos of Charles V is Carande (1987).

13 See Torres López and Pérez-Prendes (1963). De Carlos Morales (2008, pp. 95-96) shows that the Genoese were involved in the placement of 60\% of all outstanding juros.

${ }^{14}$ See Drelichman and Voth (2011) for an analysis of the king's incentive to repay.
} 
Asientos could be complex. Disbursement would often occur in distant places, and in foreign currency. Repayments mostly took place in Castile. The contracts typically specified the source to be used for servicing a specific asiento. These included general revenue, specific taxes, and the silver fleets. Juros were often used as means of repayment as well. The disbursement and repayment schedule could be staggered, increasing and reducing the bankers' exposure several times over the life of a loan. Contingent scenarios were often built into the contract, modifying the baseline cash flows if certain events occurred. Examples include the arrival date of the silver fleet or the insufficient revenue for a specific tax. Some contracts give additional options to either king or banker, such as the ability to change the repayment stream or to modify the timing of a payment; these changes could be subject to a penalty.

\subsection{The defaults}

The early defaults of 1557 and 1560 affected the debts Philip II had inherited from Charles V. These funds had been provided by German bankers. Since the systematic record at the Archive of Simancas begins in 1566, we are unable to study these early episodes. ${ }^{15}$ Our analysis begins with the Genoese system, introduced in the 1560s, and focuses on the defaults of 1575 and 1596.

In the first half of the 1570s, Castile was engaged in two major wars, one in Flanders and the other against the Ottomans. Silver remittances in 1572, 1573 and 1574 turned out to be unusually poor. Faced with high expenditures and low silver revenues, the king requested a large tax increase from the Cortes. ${ }^{16}$ An agreement was only reached in 1575 , too late to prevent the payment stop on 14.6 million ducats of asientos, as well as on the juros that served as collateral. King and bankers settled in late 1577. On average, the king repaid $62 \%$ of outstanding loans, using juros issued against the new taxes approved by the Cortes. The bankers in turn agreed to provide a new loan for five million ducats.

Between 1576 and 1583, military expenditure fell sharply. Castile's finances improved as a result. New taxes and rising silver remittances reinforced this trend. Starting in 1584, however, renewed fighting caused a turn for the worse. Philip launched a new offensive against the Dutch rebels and began preparations to invade England with the 'Invincible Armada'. Its defeat in 1588 required additional defense expenditures - the fleet needed to be rebuilt, and coastal fortifications strengthened against possible attack. These costs strained the royal treasury. Despite the introduction of new excises in 1591 - the millones - the Crown defaulted again in 1596. This affected 7 million ducats of asientos - less than half of the 1575 amount. Crown and bankers agreed on a settlement in less than a year. It involved a $20 \%$ reduction of payments due.

While Philip's defaults were spectacular events that sent shockwaves throughout European financial markets, they only affected a small proportion of Castile's obligations. Asientos constituted only a quarter of the debt stock in 1575. In 1596, shortterm loans accounted for less than $10 \%$ of total debt. The defaults of Philip II were partial: with the exception of bonds used as collateral, juros continued to be serviced without interruption. Defaults thus reflected temporary liquidity shortfalls. Compared to modern reschedulings, settlements were reached quickly. ${ }^{17}$ In the remainder of the paper, we show that lenders obtained rates of return that exceeded their opportunity cost and explore what determined the profitability of short term lending.

\section{Data}

Between 1566 and 1600, Philip Il entered into 435 asientos with his bankers. ${ }^{18}$ The contracts consist of 4997 handwritten pages. With the exception of a short standardized closing paragraph, each document is entirely composed of contractual clauses.

To estimate the rates of return for each contract, we need to reconstruct the cash flows they generated. We transcribed every single clause, converted foreign currency into ducats (the Castilian unit of account), valued the assets involved, and coded the result as an inflow or outflow for the banker at a monthly frequency. ${ }^{19}$ Whenever a clause lent itself to ambiguous interpretation, we chose the reading that resulted in a lower return for the lender. We also coded several additional variables, including the identity and family of the lender, the places of disbursement and repayment, whether a foreign exchange transaction took place and at what cost, and the type and quantity of collateral posted. We now illustrate this process with a sample contract.

The brothers Pedro and Francisco de Maluenda entered into a contract with the king on July $13,1595 .{ }^{20}$ They agreed to deliver 349,464 ducats in Lisbon in 13 payments. ${ }^{21}$ The first payment, for 26,856 ducats, was due eight days after the contract date. The

\footnotetext{
15 For a comprehensive overview of the state of knowledge about the first two defaults, see De Carlos Morales (2008).

${ }^{16}$ Lovett $(1980,1982)$ provides a general description of the 1575 crisis and its resolution. For a discussion of the interaction between the Crown and the Cortes during the crisis, see Jago (1985).

17 In Drelichman and Voth (2010), we show that Philip II's debts were sustainable overall.

18 Of the 435 contracts, 24 are damaged beyond usability or are not actually original loans, but rather pure transfers or restructurings of earlier obligations. A further 9 contain incomplete information - suitable for summary statistics but not for estimating rates of return. The empirical analysis is thus based on either 411 or 402 loans depending on the data requirements.

${ }^{19}$ To calculate amounts in different currencies, we first converted units of account into circulating coins, and then coins into their gold content. We rely on Munro (2004) for most values. When a contract mentions a specific exchange value, we use it instead.

20 AGS, Contadurías Generales, Legajo 92. 'Los dichos Francisco y Pedro de Maluenda. Asiento tomado con ellos en 13 de julio de 1595 sobre 439,500 ducados que han de proveer en Lisboa.'

21 The summary on the front page of the contract describes the principal as consisting of 349,500 ducats. These small discrepancies, in all likelihood introduced for rounding convenience, are not uncommon. The relevant amounts, which we use throughout our empirical exercises, are those in the specific clauses.
} 
Table 2

Agreed cash flows in the contract with the Maluenda brothers.

\begin{tabular}{|c|c|c|c|c|}
\hline Month & Disbursements & Repayments & Net cash flow & Description \\
\hline Jul-95 & 53,740 & & $-53,740$ & $\begin{array}{l}\text { Initial disbursement of } 26,856 \text { ducats; first monthly } \\
\text { disbursement of } 26,884 \text { ducats. }\end{array}$ \\
\hline Aug-95 & 26,884 & & $-26,884$ & Monthly disbursement. \\
\hline Sep-95 & 26,884 & & $-26,884$ & Monthly disbursement. \\
\hline Oct-95 & 26,884 & 100,890 & 74,006 & $\begin{array}{l}\text { Monthly disbursement; repayment of } 1,950 \text { ducats; repayment } \\
\text { of } 97,000 \text { ducats plus } 1 \% \text { simple interest for two months. }\end{array}$ \\
\hline Nov-95 & 26,884 & 77,250 & 50,366 & $\begin{array}{l}\text { Monthly disbursement; repayment of } 75,000 \text { ducats plus } \\
1 \% \text { simple interest for three months. }\end{array}$ \\
\hline Dec-95 & 26,884 & & $-26,884$ & Monthly disbursement. \\
\hline Jan-96 & 26,884 & & $-26,884$ & Monthly disbursement. \\
\hline Feb-96 & 26,884 & & $-26,884$ & Monthly disbursement. \\
\hline Mar-96 & 26,884 & & $-26,884$ & Monthly disbursement. \\
\hline Apr-96 & 26,884 & & $-26,884$ & Monthly disbursement. \\
\hline May-96 & 26,884 & & $-26,884$ & Monthly disbursement. \\
\hline Jun-96 & 26,884 & & $-26,884$ & Monthly disbursement. \\
\hline Jul-96 & 0 & & 0 & \\
\hline Aug-96 & 0 & & 0 & \\
\hline Sep-96 & 0 & & 0 & \\
\hline Oct-96 & 0 & 201,780 & 201,780 & $\begin{array}{l}\text { Final repayment of } 177,000 \text { ducats plus } 1 \% \text { simple interest for } \\
12 \text { months plus } 2 \% \text { lump sum bonus. }\end{array}$ \\
\hline
\end{tabular}

remaining 12 payments, of 26,884 ducats each, were due at the end of each month, starting in July 1595 . The king promised to repay as follows:

- A payment of 75,000 ducats from the general treasury in November 1595.

- A payment of 97,000 ducats one month after the arrival of the first treasure fleet.

- The amounts in the first two payments would accrue $1 \%$ monthly (simple, not compounding) interest starting from the month of August.

- A payment of 1950 ducats in October 1595 to cover miscellaneous transaction costs. The bankers did not have to itemize expenses.

- A final payment one month after the arrival of the fleet of 1596. This payment was calculated on the basis of the outstanding 177,000 ducats, plus $1 \%$ monthly interest from October 1595 , plus an additional $2 \%$ of the base amount for 'other costs'.

If the fleet of 1596 failed to reach Seville by December, the bankers had the option of requesting payment in the form of lifetime juros for the same face value as the outstanding payment, with a maximum rate of 7.14\%. Finally, there was a standard set of clauses allowing the bankers to export the bullion needed to disburse funds abroad, as well as protection against changes in the metallic content of the currency.

The Maluenda contract is relatively simple. Because the deliveries were made through letters of exchange denominated in Castilian ducats, and the repayments were made in Castile itself, no currency conversion was necessary. The only uncertainty arose from the arrival of the fleets. We assume that the bankers expected the fleets to reach Spain in September, their median arrival month (see Appendix A for a detailed discussion of this assumption). Payment was therefore expected in October. If the fleet arrived later, the monthly $1 \%$ interest charge would accrue until the payments were made or the bankers received juros. Lifetime juros have a present value that is lower than their face value. We therefore disregard the option of the banker taking them in lieu of payment when calculating ex-ante returns. ${ }^{22}$ The cash flows implied by our method are reported in Table 2.

In constructing the cash flows, we needed to adopt several conventions. The asiento described above illustrates our treatment of payments tied to the arrival of the fleets. Other assumptions relate to the valuation of juros used for repayment. As a general rule, we used the cash flows of the juros themselves, and calculated their net present value. Appendix A describes the process and assumptions.

Table 3 reports summary statistics for our data. The average loan amount was 219,000 ducats; some contracts were issued for as little as a few thousand. The largest contract, for well over 2.5 million ducats, was issued as part of the 1575 settlement. The second largest loan still exceeded 2.1 million ducats. $41 \%$ of contracts involved foreign exchange operations. The median duration was 21 months. Some contracts lasted for over 10 years, while others could be as short as a few days. The latter were usually transfers, which involved a relatively brief credit transaction as well. One third of all contracts had some collateral attached to them. The median amount collateralized was 100\% of the principal. Where it exceeded principal, it was intended to cover interest as well. Collateral could also be used to enhance the return of a contract by allowing the banker to purchase it at a discount at maturity. $19 \%$ of all contracts mention previously unmet obligations. In order to avoid double counting, we do not include these amounts in our cash flows. The king normally paid the overdue amounts in full and compensated the bankers for the additional delay. We discuss the implications of these overdue payments for profitability in more detail in Section 5.

\footnotetext{
${ }^{22}$ Bankers could request juros yielding a maximum of 7.14\%. Under our discount rate assumption (also 7.14\%), the present value of lifetime juros of any allowed yield would have been lower than their face value. We discuss this at length in Appendix A.
} 
Table 3

Summary statistics.

\begin{tabular}{|c|c|c|c|c|c|}
\hline Variable & Mean & Median & Std. dev. & Min & Max \\
\hline Principal & 219,053 & 108,333 & 317,301 & 2080 & $2,648,000$ \\
\hline Foreign exchange & $41 \%$ & & 0.49 & 0 & 1 \\
\hline Duration & 27 & 21 & 22.67 & 0 & 140 \\
\hline Collateral & $32 \%$ & & 0.47 & 0 & 1 \\
\hline$\%$ collateralized $^{a}$ & $121 \%$ & $100 \%$ & 0.66 & 0 & $612 \%$ \\
\hline Restructuring & $19 \%$ & & 0.39 & 0 & 1 \\
\hline Nominal rate ${ }^{b}$ & $9.3 \%$ & $12.0 \%$ & 0.05 & 0 & $16 \%$ \\
\hline
\end{tabular}

Note: statistics for 411 observations (except as noted); principal is the total amount ever disbursed on each contract, in current ducats; foreign exchange is a dummy variable taking the value 1 if the contract includes a foreign exchange transaction; duration is the maximum number of months a contract could be in good standing; collateral is a dummy variable taking the value 1 if any portion of a contract was collateralized; \% collateralized indicates what percentage of the capital was backed by collateral; restructuring is a dummy variable taking the value 1 if the contract restructured an earlier one; nominal rate is the interest rate explicitly stated in the contract.

a Statistics for 134 contracts with collateral.

b Statistics for 335 contracts that state an interest rate explicitly.

335 contracts explicitly specify an interest rate ('nominal rate' in Table 3). These were relatively low, and varied from 0 to $16 \%$. In an age that took a dim view of lending against interest in general, the use of low 'headline figures' is unsurprising. These are usually $9 \%$ before $1570,12 \%$ by 1575 and $16 \%$ by the end of the century. The actual rate of return of these contracts as it emerges from the cash flows was usually higher. Some contracts actually specify that the banker will receive no interest. This was typically the case when the loan funded a religious building, such as the monastery of El Escorial. Bankers that lent without interest in one transaction normally received ample compensation in the next contract. When establishing profitability it is therefore important to look beyond individual contracts, and also examine banking families as the unit of analysis.

\section{The returns to lending}

This section first describes the different measures we use to calculate the rate of return, and then reports our estimates for individual contracts, for overall lending to the king, and for lending by banking family. We next examine the correlates of contract profitability, and how lending rates evolved over time. Our main conclusion - that lending to Philip II was consistently profitable is robust to a variety of alternative assumptions.

\subsection{Measuring returns}

We use two different profitability measures to calculate the returns of contractual flows: the modified internal rate of return (MIRR) and the profit index (PI). Each has its advantages and drawbacks, which we discuss below. Virtually all our findings are robust to the choice of measure.

The MIRR is defined as the ratio between the future value of positive cash flows and the present value of negative cash flows. The formula is

$$
\text { MIRR }=\sqrt[n]{\frac{-\mathrm{FV}\left(\text { positive cash flows, } r_{r}\right)}{\mathrm{PV}\left(\text { negative cash flows, } r_{f}\right)}}-1
$$

where $n$ is the number of periods in the contract. If the lender receives positive cash flows before the end of the contract, the assumption is that they can be reinvested at rate $r_{r}$. Negative cash flows after the start of the loan are discounted at rate $r_{f}$.

Using the MIRR is attractive because of the nature of asiento contracts. The cash flow of many asientos turned from positive to negative and back several times over the lifetime of a loan. Our sample contract with the Maluenda brothers is a case in point. The obvious alternative to the MIRR is the internal rate of return (IRR), a common measure in corporate finance. It is defined as the discount rate that makes the NPV of a series of cash flows equal to zero. The IRR is unsuitable to our data. It performs well only in the case of simple cash flows, with a single disbursement followed by a single repayment. Whenever there are intermediate cash flows, two problems arise. First, the IRR formula assumes that any intermediate positive cash flows can be reinvested at the same rate of return as the entire project. This is unrealistic; there was no infinitely elastic demand for loan contracts by the Crown. The banker's obvious alternative was to invest repayments in juros. Because juros yielded less than asientos, the IRR would overestimate the profitability of the contract. Second, intermediate negative cash flows can cause the IRR formula to yield multiple solutions, or none at all. Since most asientos specified staggered disbursements and intermediate repayments, we do not use the IRR.

The MIRR has the advantage of yielding a unique solution. In the absence of intermediate cash flows, it is identical to the IRR. Just as the IRR, it can be interpreted as the rate of return that makes the NPV of the project equal to zero. The MIRR requires explicit assumptions about the reinvestment and the finance rate. For our benchmark estimates, we use the juro yield of $7.14 \%$ as the 
Table 4

Cash flows and profitability of the contract with the Maluenda brothers.

\begin{tabular}{|c|c|c|c|}
\hline & Original agreement & Settlements & Repudiation \\
\hline Jul-95 & $-53,740$ & $-53,740$ & $-53,740$ \\
\hline Aug-95 & $-26,884$ & $-26,884$ & $-26,884$ \\
\hline Sep-95 & $-26,884$ & $-26,884$ & $-26,884$ \\
\hline Oct-95 & 74,006 & 74,006 & 74,006 \\
\hline Nov-95 & 50,366 & 50,366 & 50,366 \\
\hline Dec-95 & $-26,884$ & $-26,884$ & $-26,884$ \\
\hline Jan-96 & $-26,884$ & $-26,884$ & $-26,884$ \\
\hline Feb-96 & $-26,884$ & $-26,884$ & $-26,884$ \\
\hline Mar-96 & $-26,884$ & $-26,884$ & $-26,884$ \\
\hline Apr-96 & $-26,884$ & $-26,884$ & $-26,884$ \\
\hline May-96 & $-26,884$ & $-26,884$ & $-26,884$ \\
\hline Jun-96 & $-26,884$ & $-26,884$ & $-26,884$ \\
\hline \multicolumn{4}{|l|}{ Jul-96 } \\
\hline \multicolumn{4}{|l|}{ Aug-96 } \\
\hline \multicolumn{4}{|l|}{ Sep-96 } \\
\hline Oct-96 & 201,780 & & \\
\hline . & & . & \\
\hline . & & . & \\
\hline . & & . & \\
\hline Oct-97 & & 137,059 & \\
\hline Yearly MIRR & $12.5 \%$ & $-5.3 \%$ & $-61.1 \%$ \\
\hline Yearly PI & $6.8 \%$ & $-14.8 \%$ & $-55.4 \%$ \\
\hline
\end{tabular}

reinvestment rate, and $5 \%$ as the finance rate. These are conservative choices intended to produce lower bound estimates of profitability. Appendix B discusses them in detail. We also conduct sensitivity analysis with alternative parameter values.

The profit index is defined as the NPV of a contract divided by capital at risk. Its advantage over the MIRR is that it only requires specifying one discount rate. The drawback is that the concept of 'capital at risk' is not well defined when there are multiple staggered disbursements and repayments. Disbursements increase capital at risk, while repayments diminish them. A long contract with a single repayment at the end exposes the lender to more risk than one where much of the loan is repaid quickly. We measure capital at risk as the total amount disbursed over the life of the contract. This overstates the true exposure, which was reduced by intermediate repayments. We also do not discount future disbursements, but rather use their full value. In combination, these assumptions introduce a downward bias.

The main difference between the MIRR and the PI is that the former is a gross measure, while the latter is net of the opportunity cost - which we take to be the juro yield. To compare them, the juro rate must be first subtracted from the MIRR. Next, the discount rates used differ conceptually. In the MIRR, the reinvestment and finance rates refer to the yield of alternative assets. In the PI, the discount rate is a subjective measure that combines the opportunity cost of funds and the risk aversion of the investor. Finally, as we discuss in the analysis, the MIRR is not well suited to evaluating long loans. When maturity is relevant, we use the PI instead.

\subsection{Scenarios}

We derive our data from the contracts as agreed between king and bankers. In many cases, the original agreement was not respected to the letter. 119 contracts were affected by the 1575 or the 1596 bankruptcy. Delays in both disbursements and repayments were common even in normal times. Almost $20 \%$ of loans contain clauses rescheduling previously unfulfilled obligations. Without observing the actual cash flows, we cannot derive precise measures of ex-post profitability. Nonetheless, we can bound the likely returns. We do so by using our knowledge of the defaults and their settlements to approximate the cash flows that actually occurred.

First, we calculate the profitability of each contract assuming that its clauses were respected to the letter. This is our upper bound. Next, we consider what would have happened if, in the 1575 and 1596 bankruptcies, the king had repudiated all the outstanding debt. This yields a (very low) lower bound. ${ }^{23}$ Finally, we approximate the actual cash flows by estimating the settlement payments made by the king on each contract affected by the defaults. To illustrate the three scenarios, we return to the contract with the Maluenda brothers.

The first column in Table 4 reproduces the cash flows agreed in the original contract. Using our benchmark reinvestment and finance rate, the expected MIRR was $12.5 \%$, a healthy $5.4 \%$ above the juro rate. The PI was $6.8 \%$. In October 1596, however, the king decreed the fourth suspension of payments of his reign. The fleet of 1596 did not arrive until late October, and hence we know with certainty that the final payment of the contract did not take place. ${ }^{24}$ Had the king repudiated the outstanding debt, the returns would have been strongly negative. Note that the majority of contracts would not have had such poor returns even under

\footnotetext{
${ }^{23}$ Note that it is not realistic to assume that any one banker could have earned a return as low as the one implied by this scenario - he would in all likelihood not have lent again after 1575 .

${ }^{24}$ We use the dates of arrival of the fleets in Morineau (1985).
} 
Table 5

MIRR estimates (all contracts, 1566-1600, annualized rates).

\begin{tabular}{|c|c|c|c|c|}
\hline Reinvestment rate (\%) & Finance rate (\%) & Original agreement (\%) & Settlements (\%) & Repudiation (\%) \\
\hline 0.00 & 0.00 & 15.7 & 11.6 & 3.0 \\
\hline 5.00 & 0.00 & 17.7 & 13.6 & 5.1 \\
\hline 7.14 & 0.00 & 18.6 & 14.5 & 6.0 \\
\hline 10.00 & 0.00 & 19.8 & 15.7 & 7.2 \\
\hline 0.00 & 5.00 & 16.7 & 12.5 & 4.0 \\
\hline 5.00 & 5.00 & 18.8 & 14.6 & 6.1 \\
\hline 7.14 & 5.00 & 19.7 & 15.5 & 7.0 \\
\hline 10.00 & 5.00 & 20.9 & 16.7 & 8.2 \\
\hline
\end{tabular}

repudiation. Most were repaid partially or fully before the defaults took place. Bankers who had not disbursed the full loan amount could have stopped further payments. The Maluenda contract illustrates what could have happened in a worst-case scenario to a particularly unlucky set of bankers. In actual fact, such a dire scenario did not materialize. The king agreed to repay $80 \%$ of outstanding debts in October 1597. The 'settlement' column reports our estimate of the actual cash flow. Since the language in most contracts does not distinguish between capital repayment and interest, we assume that all payments go towards capital amortization first. This produces a lower bound for outstanding capital at the time of the default, and hence for the settlement payment. By this methodology, as of October 1596, the king would have owed the Maluenda brothers 171,324 ducats from this particular contract. ${ }^{25}$ We multiply this amount by 0.8 and enter it as a positive cash flow in October 1597. This yields a MIRR of $-5.3 \%$ (quite comparable to the PI of $-14.8 \%)^{26}$

While the 1597 settlement imposed a uniform 20\% reduction on outstanding claims for all contracts, terms varied in 1575 according to how a contract was collateralized. ${ }^{27}$ Bankers that held standard juros as collateral recovered 70\% of their claims; bankers holding juros guaranteed by the Casa de la Contratación received 55\%; uncollateralized loans were granted $42 \%$. For contracts affected by the 1575 default, we calculate the recovery rates for each contract based on the type of collateral used.

\subsection{Overall profitability of lending}

We first consider overall short-term lending to Philip II. Did bankers on the whole - i.e. when aggregated into a fictitious single financial entity for the years 1566-1600 - make money by lending to the king? Table 5 reports 24 profitability estimates - MIRRs for three repayment scenarios, each for eight pairs of reinvestment and finance rates. These are averages of each contract's MIRR, weighted by the amounts disbursed. Our benchmark estimate, using a reinvestment rate of $7.14 \%$ and a finance rate of $5 \%$, is shown in bold.

Average returns as stipulated in the original agreements were above 15\%. Philip's bankers did not sign up to lose money. This is true independently of the finance and reinvestment rate used. That lending was profitable is borne out clearly in the 'repudiation' column. It shows that the bankruptcies would not have been catastrophic for lenders even if they had failed to recover a single ducat. Combining this assumption with the lower bounds for both reinvestment and finance rates, lenders would have obtained an annualized return of $3 \%{ }^{28}$ This would not have covered their opportunity costs in full, but it would not have led to capital losses. If more realistic parameters are used, lenders' profits come close to or exceed the opportunity cost even under a complete repudiation scenario.

The 'settlements' column gives our (conservative) best guess of actual returns. The most pessimistic value is again obtained when setting both the reinvestment and the finance rates equal to zero. Even under this extreme assumption, which essentially holds that bankers had no alternative use for their cash, the overall return is $11.6 \%$, almost $4.5 \%$ above the yield of long-term debt. Our benchmark estimate uses a more realistic 7.14\% reinvestment rate and 5\% finance rate. In that case, short-term lending yielded a return of $15.5 \%$, more than double that of long-dated bonds.

As is apparent from Table 5, the MIRR reacts differentially to different finance and reinvestment rate assumptions. Intermediate negative cash flows are relatively small. Hence, the finance rate has little impact on the overall result. Sensitivity is greater for the reinvestment rate. All the results in Table 5 are preserved when we use the profit index instead of the MIRR as our profitability measure. Appendix $\mathrm{C}$ reports the actual values.

\subsection{Profitability by family}

While the results presented so far show that lending to Philip II was profitable even under very unfavorable assumptions, average returns can mask considerable variation across lenders. We now examine rates of return by family.

\footnotetext{
25 Because the clause structure in this particular contract is detailed, it is possible to calculate that outstanding capital at the time of the default was 177,000 ducats. Its MIRR would have therefore been $-4.6 \%$. Few contracts contain similar detail. We therefore apply the 'capital amortization first' methodology uniformly.

${ }^{26}$ While the Maluenda brothers lost money on this particular contract, their overall relationship with the king was profitable. They lent over 4.3 million ducats to Philip II, realizing a MIRR of $20.6 \%$ after taking into account the effects of the defaults.

27 We describe the terms of each medio general in full detail in the appendix to the online version of Drelichman and Voth (2010).

${ }^{28}$ Note that the first derivative of the MIRR with respect to the finance rate is positive, and hence the value of the finance rate that produces a lower bound is zero. Appendix B explains this behavior in detail.
} 
Between 1566 and 1596, 145 different bankers belonging to 78 families engaged in business with Philip II. However, only 127 bankers, belonging to 60 families, ever risked capital. The rest provided intermediation services without putting their own resources on the line. We therefore analyze only the profitability of the 60 families engaged in lending.

Table 6 reports the MIRR by family for the 1566-1600 period. As before, we use the amounts disbursed to calculate a weighted average. Families are ranked by the total amount lent over the period as a whole. Credit provision was heavily concentrated. The

Table 6

MIRR by family (1566-1600, annualized rates).

\begin{tabular}{|c|c|c|c|c|}
\hline Family name & Original agreement (\%) & Settlements (\%) & Repudiation (\%) & Total amount ever disbursed \\
\hline Spinola & 20.6 & 19.3 & 16.8 & $16,359,959$ \\
\hline Grimaldo & 18.6 & 11.7 & 2.6 & $7,306,110$ \\
\hline Lomelin & 23.8 & 17.3 & 0.8 & $5,219,088$ \\
\hline Fucar & 11.4 & 6.2 & -3.8 & $4,951,107$ \\
\hline Maluenda & 26.1 & 20.6 & 10.9 & $4,360,131$ \\
\hline Torre & 22.2 & 16.1 & 3.0 & $4,142,326$ \\
\hline Espinosa & 12.0 & 8.4 & 6.8 & $3,405,119$ \\
\hline Centurion & 19.3 & 17.2 & 10.9 & $3,253,726$ \\
\hline Gentil & 19.9 & 15.6 & 8.8 & $2,927,399$ \\
\hline Marin & 20.1 & 20.0 & 19.3 & $2,646,472$ \\
\hline Vitoria & 19.4 & 10.4 & -19.7 & $2,063,816$ \\
\hline Doria & 23.8 & 13.8 & -4.1 & $2,027,106$ \\
\hline Judice & 27.0 & 27.0 & 27.0 & $1,697,703$ \\
\hline Latorre & 11.5 & 11.5 & 11.5 & $1,489,818$ \\
\hline Carlessequi & 16.1 & 16.1 & 16.1 & $1,425,315$ \\
\hline Cataneo & 21.5 & 7.6 & -5.1 & $1,226,934$ \\
\hline Isunza & 25.0 & 24.8 & 23.6 & $1,171,464$ \\
\hline Ruiz & 9.9 & 7.5 & -7.9 & $1,140,276$ \\
\hline Salamanca & 11.8 & 11.8 & 11.8 & $1,005,657$ \\
\hline Fiesco & 24.5 & 16.6 & -5.0 & 995,290 \\
\hline Fornari & 16.7 & 8.1 & -8.6 & 940,188 \\
\hline Grillo & 27.8 & 21.4 & 12.6 & 930,411 \\
\hline Justiniano & 25.9 & 15.9 & -11.4 & 786,673 \\
\hline De Negro & 18.1 & 13.8 & -12.9 & 769,407 \\
\hline Pasqual & 21.8 & 16.1 & 16.1 & 582,976 \\
\hline Lercaro & 12.4 & 3.1 & -13.2 & 551,300 \\
\hline Suarez & 22.2 & 21.0 & 20.5 & 525,413 \\
\hline Isla & 10.8 & 10.8 & 10.8 & 497,175 \\
\hline Serra & 8.0 & 2.9 & -12.3 & 458,178 \\
\hline Herrera & 10.8 & 10.8 & 10.8 & 451,234 \\
\hline Galletto & 13.9 & -11.3 & -100.0 & 407,817 \\
\hline Carmona & 17.8 & 17.8 & 17.8 & 395,333 \\
\hline Salazar & 17.8 & 17.8 & 17.8 & 395,333 \\
\hline Pinelo & 15.8 & 15.8 & 15.8 & 341,405 \\
\hline Mena & 17.0 & 10.6 & -6.0 & 306,982 \\
\hline Murain & 8.1 & 8.1 & 8.1 & 299,000 \\
\hline Cambi & 9.6 & 8.3 & 6.7 & 275,549 \\
\hline Salinas & 17.3 & -10.5 & -22.7 & 264,440 \\
\hline Adorno & 31.0 & 31.0 & 31.0 & 230,938 \\
\hline Curiel de la Torre & 151.1 & 151.1 & 151.1 & 186,309 \\
\hline Sauli & 21.7 & 5.8 & -30.0 & 126,605 \\
\hline Corvari & 23.4 & 23.4 & 23.4 & 119,224 \\
\hline Diaz Aguilar & 9.9 & 9.9 & 9.9 & 118,480 \\
\hline Sabago & 16.5 & 16.5 & 16.5 & 100,155 \\
\hline Obada & 8.3 & 8.3 & 8.3 & 100,000 \\
\hline Franquis & 9.4 & 9.4 & 9.4 & 83,000 \\
\hline Villaldo & 20.5 & 20.5 & 20.5 & 77,409 \\
\hline Aponal & 32.1 & 32.1 & 32.1 & 67,026 \\
\hline Salucio & 78.2 & 78.2 & 78.2 & 60,027 \\
\hline Interiano & 31.1 & 31.1 & 31.1 & 53,333 \\
\hline Calvo & 12.4 & 12.4 & 12.4 & 50,000 \\
\hline Serna & 12.9 & 12.9 & 12.9 & 30,581 \\
\hline Vicuña & 12.9 & 12.9 & 12.9 & 30,581 \\
\hline Palavecin & 8.6 & -5.5 & -50.7 & 28,601 \\
\hline Cibo & 67.3 & 67.3 & 67.3 & 19,624 \\
\hline Picamillo & 15.6 & 15.6 & 15.6 & 16,184 \\
\hline Rastrogago & 19.1 & 19.1 & 19.1 & 15,000 \\
\hline Lago & 19.1 & 19.1 & 19.1 & 15,000 \\
\hline San Vitores & 8.6 & -4.9 & -45.3 & 6110 \\
\hline Bobadilla & 10.0 & -0.6 & -14.8 & 2080 \\
\hline
\end{tabular}

Note: The reinvestment rate is assumed to be $7.14 \%$, the finance rate $5 \%$. The amounts disbursed are expressed in ducats. We use the Spanish spellings of the family names, as they appear in the archival documents. 


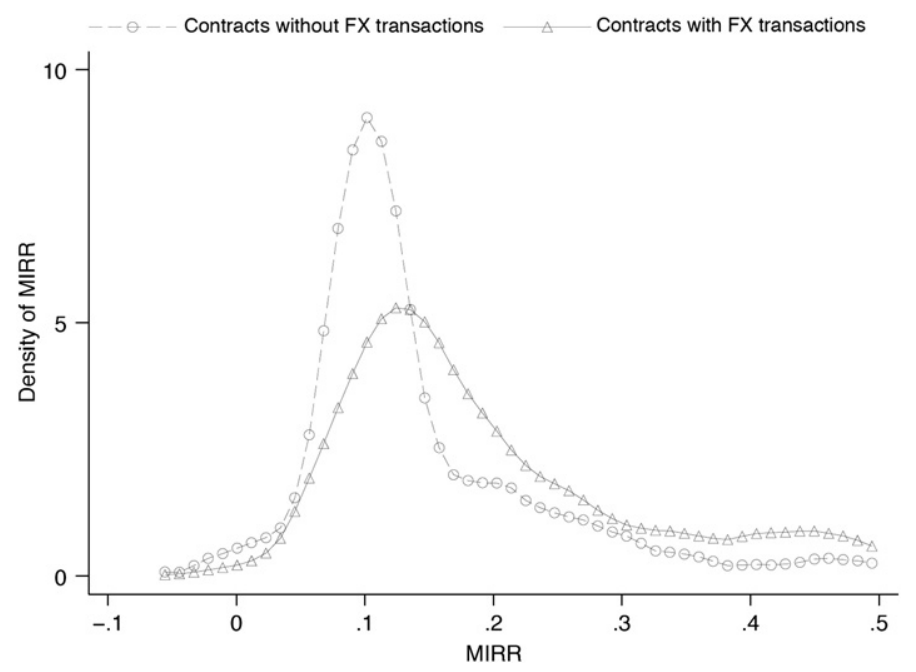

Fig. 1. Density of MIRRs by foreign exchange clauses.

Spinola family, which counted 12 active members, lent over $20 \%$ of all funds. The top 10 families provided just short of $70 \%$ of all loans, and 19 families lent over 1 million ducats each. ${ }^{29}$

Rates of return varied considerably by family. No family agreed to compensation below the $7.14 \%$ juro rate. ${ }^{30}$ In the event of a complete repudiation, 18 families would have lost money. The remaining 42 families, however, would have realized positive rates of return; 37 of them would have earned more than the juro rate. ${ }^{31}$

According to our best estimate of actual profitability, only five families had a negative MIRR; fully 51 earned more than the long-term bond yield. Of the five families that actually lost money, three invested little: 2080, 6110 and 28,601 ducats respectively. All five entered into one or two contracts with the king, closely before the defaults. The Galletto and Salinas families sustained losses on somewhat larger contracts, but their rates of return, $-11.3 \%$ and $-10.5 \%$, are hardly catastrophic. ${ }^{32}$ The absolute losses of these five families amount to just over 75,000 ducats. This is less than $0.1 \%$ of total short-term lending to Philip II.

According to the 'settlement' scenario, four families did not lose money in absolute value but failed to earn the juro rate. One of these was the Fucar (Fugger) family. As a matter of fact, the Fugger were the only family exempted from the provisions of the 1575 bankruptcy. ${ }^{33}$ Their actual rate of return, therefore, was the originally contracted $11.4 \%$. The other three families were the Lercaro (3.1\%), Serra (2.9\%) and Sauli (5.8\%). The last two had only a sporadic relationship with the king, and happened to lend just prior to the defaults. The Lercaro lent somewhat larger amounts throughout the entire period - just over 550,000 ducats. These loans were provided in the run-up to the bankruptcies, and the reduction in payment obligations caused them earn less than they would have by investing in juros.

Three of the MIRRs reported in Table 6 are unusually high. Juan Curiel de la Torre earned over $151 \%$ on lending of some 186,000 ducats. The Salucio and Cibo families also earned in excess of 50\%. Curiel de la Torre achieved such a high return through a combination of factors. He had high returns on small contracts, and he kept his exposure to a minimum by staggering disbursements and repayments. ${ }^{34}$ The Salucio and Cibo lent little, and hence did not obtain large absolute gains.

\subsection{Correlates of return rates}

Table 6 reveals considerable heterogeneity in the rate of returns at the family level. Across individual loans, the spread is even more marked. What explains the cross-section of returns to lending? Were some bankers obtaining preferential treatment? Or does the variation mostly reflect the different characteristics of each loan?

\footnotetext{
${ }^{29}$ We have already examined the concentration of lending in Drelichman and Voth (2011). Our previous results differ from the current ones in the order of one percentage point. The reason is that in our previous paper we included pure transfers, while here we focus on capital actually at risk.

30 This validates our choice of the juro rate as an upper bound for the opportunity cost of funds.

${ }^{31}$ Note that families that were not affected by the defaults have the same rate of return under each of the three scenarios.

32 In fact, the Galletto family signed its only contract just four days before the 1596 bankruptcy. In all likelihood the disbursement was never made, and the family did not suffer any losses. We nonetheless assume the contract was carried out in order to bias the results against finding profitability. The repudiation scenario, therefore, shows a profitability of $-100 \%$ - the family would have lost the entire amount disbursed.

${ }^{33}$ In this way, the Fugger were compensated for the continued provision of transfer services during the payment moratorium. See Drelichman and Voth (2011) for a discussion of the rationale for this exemption.

34 We calculate profitability using the net disbursements as weights for each individual contract. Curiel's disbursements were timed to coincide with repayments from the king. Even though the contracts were nominally for large amounts, his actual net exposure was low, and hence his returns on capital at risk were high. The effect is particularly noticeable because he did not lend very large amounts.
} 


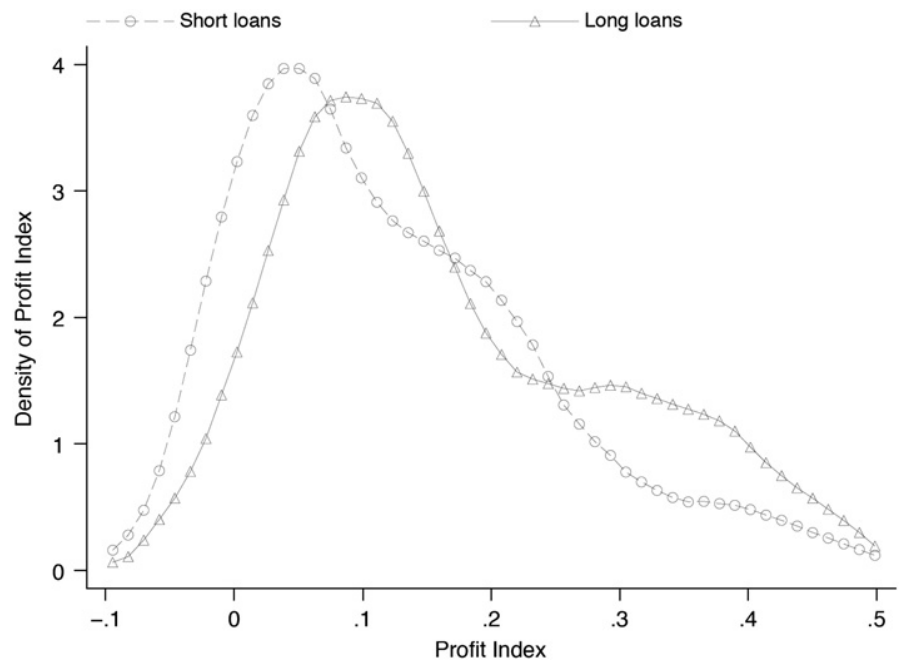

Fig. 2. Density of PIs by loan maturity.

We begin by examining some of the patterns of association between contract characteristics and the lending rate agreed. The first factor to note is that many loans contained a foreign exchange component. These are, on average, more expensive. Fig. 1 plots the density functions of the profitability for loans with and without an explicit foreign currency clause. While there is a lot of variation in the interest rates charged, the difference in the means and modes is clear. Loans with a foreign exchange component had an unweighted mean (median) interest rate of 27\% (17\%); those without, of 19\% (11\%). Thus, the cost to the Crown of contracting debts that also involved payments (normally, disbursements) in foreign specie raised the cost of a loan by 6-9\% on average.

The second factor that influenced the cost of loans was the maturity of the loan. Since the MIRR is not well suited to evaluate loans of long maturity, we use the PI instead. ${ }^{35}$ Loans with above-median maturity (more than 22 months) often attracted markedly higher interest rates. Fig. 2 plots the distributions. The unweighted mean (median) PI for long loans is $24 \%$ (13\%), while that for short loans is $17 \%(11 \%)$.

After exploring some of the basic patterns, we continue our analysis in a multivariate setting. We do so by regressing a profitability measure $\pi$ on FX, a dummy variable for the use of foreign exchange clauses, COLL, a dummy for the use of collateral clauses, DUR, the maturity of the loan in months, PRIN, the total principal involved (abstracting from pure transfers), and $N$, a measure of the nationality of the lenders:

$$
\pi=C+\beta_{1} \text { FX }+\beta_{2} \text { COLL }+\beta_{3} \text { DUR }+\beta_{4} \text { PRIN }+\beta_{5} N+\varepsilon
$$

One obvious problem with this approach is that our explanatory variables are not exogenous. The interest rate charged is the result of a bargaining process which simultaneously involved discussions about the use of collateral, the length of the loan, the use of foreign exchange clauses, and the like. None of the variation in the right-hand side variables is arguably determined in a way that is independent of the profitability measure. We do not claim that regressions along the lines of (1) uncover causal relationships. Instead, we think of the $\beta$-coefficients as measures of broad association between observable loan characteristics.

Table 7 examines the correlates of profitability, as originally agreed in each contract. Those with a foreign exchange clause saw between 6.5\% and 9.3\% higher returns, a substantial premium. Contracts using collateral also attracted a higher return. This suggests that they involve riskier types of lending overall. Lending for longer raised the interest charged. ${ }^{36}$ Smaller contracts were also marginally more expensive, but the estimated effect is not significantly different from zero. ${ }^{37}$ Finally, the nationality of the lenders mattered. Those contracted with only German lenders attracted a markedly lower rate of return, while the Genoese did not lend at particularly favorable rates when compared with the Spaniards (excluded group). ${ }^{38}$ When we add family dummies (not reported), their coefficients are almost always insignificant.

\footnotetext{
${ }^{35}$ The MIRR assumes that all intermediate positive cash flows are reinvested at the exogenously assumed reinvestment rate until the end of the contract. For long loans, this biases the estimated profitability towards the reinvestment rate. The PI is independent of loan maturity.

${ }^{36}$ This result is based on the PI regressions. Since the MIRR has a downward bias that increases with the length of the contract, the negative duration sign on the MIRR regressions is neither surprising nor informative. The bias is related to the compound interest accumulated on intermediate positive cash flows. We control for it with a quadratic term.

${ }^{37}$ At a time when the concept of compounding was still in its infancy, there was a general tendency for short-term loans to be relatively more costly (Temin and Voth, 2006).

${ }^{38}$ The regression exercise does not allow us to determine if the higher returns for Spaniards and Genoese attest to their 'insider' role, or reflect the fact that German lenders only participated in particularly safe loans.
} 
Table 7

Cross-sectional regressions.

\begin{tabular}{|c|c|c|c|c|c|c|}
\hline & $(1)$ & (2) & (3) & (4) & (5) & (6) \\
\hline & \multicolumn{3}{|c|}{ MIRR } & \multicolumn{3}{|c|}{ PI } \\
\hline FX & $0.085^{* * *}(2.65)$ & $0.080^{* * *}(2.60)$ & $0.093^{* * *}(2.82)$ & $0.065^{* *}(2.50)$ & $0.069^{* * *}(2.68)$ & $0.079^{* * *}(2.86)$ \\
\hline Collateral & & $0.062^{* *}(2.15)$ & $0.057^{*}(1.90)$ & & $0.058^{* *}(2.09)$ & $0.050 *(1.79)$ \\
\hline Duration & & $-0.010^{* * *}(-4.69)$ & $-0.010^{* * *}(-4.71)$ & & $0.002^{* * *}(2.94)$ & $0.002^{* * *}(3.13)$ \\
\hline Duration sq. & & $6.38 \mathrm{E}-5^{* * *}(3.96)$ & $6.74 \mathrm{E}-5^{* * *}(3.96)$ & & & \\
\hline Loan size & & & $-6.78 \mathrm{E}+8(-1.51)$ & & & $-5.24 \mathrm{E}-8(-1.31)$ \\
\hline Genoese & & & $-0.015(-0.57)$ & & & $-0.003(-0.10)$ \\
\hline Germans & & & $-0.093^{* * *}(-2.57)$ & & & $-0.112^{* * *}(-3.17)$ \\
\hline Constant & $0.192^{* * *}(9.38)$ & $0.367^{* * *}(6.91)$ & $0.380^{* * *}(6.60)$ & $0.177^{* * *}(10.27)$ & $0.098^{* * *}(3.99)$ & $0.102^{* * *}(4.15)$ \\
\hline$N$ & 402 & 402 & 402 & 402 & 402 & 402 \\
\hline$R^{2}$ & 0.017 & 0.107 & 0.112 & 0.015 & 0.071 & 0.079 \\
\hline
\end{tabular}

Significance levels: ${ }^{*}=10 \%,{ }^{* *}=5 \%,{ }^{* * *}=1 \%$.

Table 8

Correlates of losses during the defaults.

\begin{tabular}{|c|c|c|c|c|c|c|}
\hline \multirow[b]{2}{*}{ Dep. var. } & (1) & $(2)$ & (3) & (4) & (5) & (6) \\
\hline & \multicolumn{3}{|c|}{ LOSS_MIRR } & \multicolumn{3}{|c|}{ LOSS_PI } \\
\hline FX & $-0.036^{* * *}(-2.58)$ & $-0.036^{* * *}(-2.61)$ & $-0.044^{* * *}(-2.76)$ & $-0.055^{*}(-1.85)$ & $-0.056^{*}(-1.93)$ & $-0.076^{* *}(-2.34)$ \\
\hline Collateral & & $0.037^{* * *}(2.88)$ & $0.039^{* * *}(2.84)$ & & $0.063^{*}(1.92)$ & $0.065^{*}(1.75)$ \\
\hline Duration & & $-0.002^{\text {**** }}(-3.00)$ & $-0.002^{* * *}(-3.00)$ & & $-0.003^{* * *}(-3.01)$ & $-0.004^{* * *}(-3.00)$ \\
\hline Duration sq. & & $1.47 \mathrm{E}-5^{\text {*** }}(2.67)$ & $1.36 \mathrm{E}-5^{* *}(2.43)$ & & & \\
\hline Loan size & & & $4.68 \mathrm{E}+8^{* *}(2.18)$ & & & $9.72 \mathrm{E}-8^{*}(1.70)$ \\
\hline Genoese & & & $0.011(0.72)$ & & & $0.050(1.36)$ \\
\hline Germans & & & $0.005(0.19)$ & & & $0.000(0.00)$ \\
\hline Constant & $-0.041^{* * *}(-7.21)$ & $-0.020(-1.61)$ & $-0.025^{* *}(-2.08)$ & $-0.117^{* * *}(-6.84)$ & $-0.042 *(-1.75)$ & $-0.055^{* *}(-2.29)$ \\
\hline$N$ & 400 & 400 & 400 & 400 & 400 & 400 \\
\hline$R^{2}$ & 0.020 & 0.048 & 0.057 & 0.009 & 0.082 & 0.094 \\
\hline
\end{tabular}

Significance levels: ${ }^{*}=10 \%,{ }^{* *}=5 \%,{ }^{* * *}=1 \%$.

The overall explanatory power of our regressions is modest. The best-performing specifications in Table 7 explain a little over $11 \%$ of total variation of lending rates. While not satisfactory overall, these results are similar to those found in the modern finance literature. ${ }^{39}$

On average, the general settlements caused losses for the lenders. What explains the cross-section of these differences? We define the variable LOSS_MIRR as the difference between the MIRR according to the settlement, and the promised MIRR, as per the original agreement. LOSS_PI is defined analogously. Table 8 shows the correlations between these measures and a set of loan characteristics. Loans with a foreign exchange component typically did quite poorly. This reflects the fact that the defaults happened in times of intense military strife, when most loans where contracted for delivery in foreign battlefields. Loans with a high collateral component showed higher returns; since the settlements took the presence of collateral into account when determining the haircuts, this is not surprising. Longer durations are unambiguously associated with greater losses, while larger loans did somewhat better. Nationality did not confer a particular advantage when negotiating the settlements, nor were specific families favored over others. In combination, these two sets of regressions suggest that the heterogeneity in the rates of return and the losses sustained during the defaults were determined by the features of each particular loan, and did not reflect the particular negotiating position of a given set of bankers.

\subsection{Profitability over time}

How did lending rates change over time? Did the defaults make lending more expensive for the king? Is there evidence of mounting "debt intolerance"? Fig. 3 plots the volume of lending and its profitability over time. The line, indexed to the left-hand axis, shows the weighted average of the ex-post MIRRs of contracts according to the year in which they were signed. The bars show the volume of actual lending every year. ${ }^{40}$

\footnotetext{
39 Berger and Udell (1995), Petersen and Rajan (1994, 1995) find R-squared values of around 0.06-0.15 in modern-day data.

40 This was calculated by adding up the disbursements that actually took place in the context of each contract, and assigning the total disbursed amount to the year in which the contract was signed.
} 


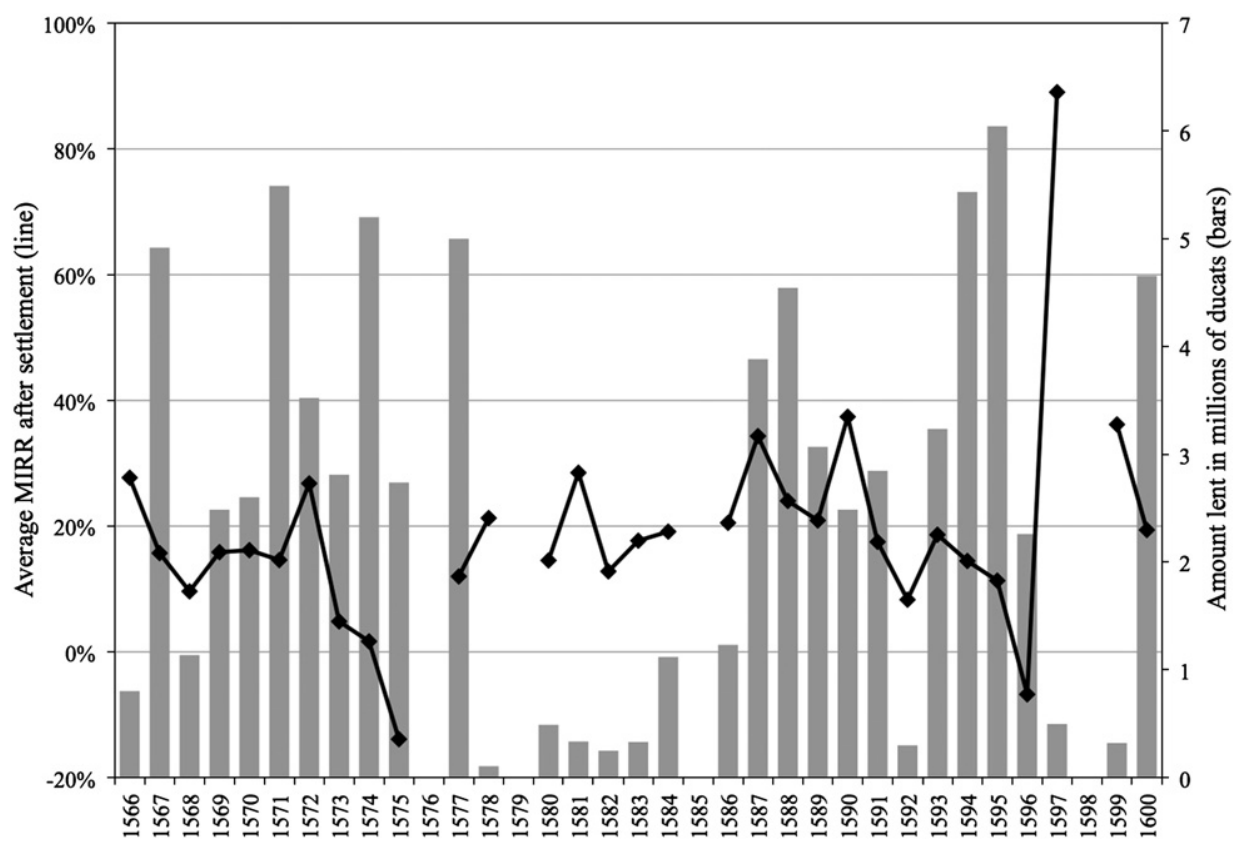

Fig. 3. Profitability and volume of lending.

MIRRs fluctuated between 15 and 30\%. The exceptions are the defaults and the 1597 outlier. ${ }^{41}$ Only contracts signed in 1573 , 1574, 1575 and 1596 failed to earn the juro rate. There is virtually no correlation between MIRRs and lending volume - the correlation coefficient is -0.27 , and falls to -0.16 if the year 1597 is removed from the sample. With the exception of a single contract signed in 1597 for a relatively small amount, there are no major spikes in rates.

Table 9 shows the average differential between ex-ante and ex-post MIRRs for contracts signed in the years leading up to each bankruptcy. The 1575 default was substantially more severe than the 1596 one. Consequently, the gap between contracted and actual rates was higher in the years leading up to 1575. The contracts affected were of longer duration - as much as 7 years in 1575 , versus a maximum of four in 1596. The amount defaulted upon in 1575 was 14.6 million ducats and the average haircut 38\%; in 1596, the king stopped servicing 7 million ducats of debt and negotiated a reduction of outstanding claims by $20 \%$. These numbers reflect the severity of each fiscal crisis. In 1575, two simultaneous campaigns, three unusually poor fleets, and the reluctance of the Cortes to increase taxes led to a serious cash flow shortfall. In 1596, in contrast, taxes had already increased substantially. The liquidity shortfall was caused by a single delayed fleet, which arrived soon after the payment stop. Similarly to an insurance contract, the losses suffered by lenders were larger when the fiscal situation was more pressing.

\subsection{Net rates of return}

In our benchmark scenario, bankers obtained an average ex-post gross MIRR of $15.5 \%$. To obtain a net measure of profitability, we need to subtract costs. Unfortunately, we do not observe most costs at the contract level. We instead use the available information on their general range to estimate the effect on the average rate of return. We conclude that costs were not sufficient to overturn the result that lending was profitable. However, they likely reduced our apparently high rates of return to a normal range.

The most important cost - that of financing - is captured by the long-term bond rate. Next, we need to consider the costs of intermediation. Lenders relied on a correspondent network. Its burden is reflected in the charges for issuing letters of exchange. Between 1566 and 1575, most contracts required disbursements either in cash at the treasury or via a letter of exchange drawn on a specific fair. When the latter was requested, the king was charged an additional $0.5 \%$ of the principal. ${ }^{42}$ In addition, most bankers

\footnotetext{
41 The outlier in 1597 was caused by a single contract for 586,000 ducats signed with several bankers affected by the default (AGS, Contadurías Generales, Legajo 93, 'Francisco y Pedro de maluenda, Nicolas Doria, Marco Antonio Judice, Nicolas de Fornari y otros, asiento tomado con ellos sobre 600,000 escudos que han de proveer en Flandes, y 76,000 ducados que se les han de pagar de los que se les deben'). This contract had a MIRR of 89\%, achieved by repaying a 40\% premium on the amount borrowed over just six months. We don't know the reasons for this rich return, and none are stated in the contract. Perhaps the king was compensating this particular group of bankers for the losses sustained in the 1596 default. Because this was the only contract signed in 1597, its MIRR is also the yearly average in our series.

${ }^{42}$ When a cash disbursement at the court was requested, the specific language was 'en esta corte en reales de contado.' Because bankers or their agents resided and collected their payments whenever the court was stationed, this type of transaction would have carried the lowest transaction costs. When a disbursement was needed at a payments fair, either in Castile or abroad, the language was 'en feria de [specific fair], en banco con cinco al millar' - that is, as a bank draft with a five per thousand surcharge.
} 
Table 9

Difference between average contracted and actual MIRRs.

\begin{tabular}{lc}
\hline Year contract was signed & 1575 default $(\%)$ \\
\hline Year of default & 30.9 \\
$t-1$ & 1596 default $(\%)$ \\
$t-2$ & 16.8 \\
$t-3$ & 11.6 \\
$t-4$ & 3.1 \\
$t-5$ & 1.7 \\
$t-6$ & 0.4 \\
$t-7$ & 0.7 \\
\hline
\end{tabular}

did not risk their own capital, but instead acted as intermediaries, splitting the contracts into smaller parts and selling them to individual investors. Their typical fee for this service was $1 \%$.

Two other important sources of cost were currency conversions and transportation of bullion. Contracts with a foreign exchange component often specify that the banker will be reimbursed for "what is customary among businessmen. ${ }^{43}$ Sometimes the king requested an affidavit signed by three or four independent bankers attesting to the costs incurred. The king covered the largest component of transport cost directly, by providing free space on his ships. Because these costs were either reimbursed on top of all other payments to the bankers or incurred directly by the king, they do not affect the rate of return. ${ }^{44}$

Several contracts include specific allowances for other costs. Our sample contract with the Maluenda brothers is a good example. The king agreed to pay the bankers a total of 5490 ducats to cover any costs they might incur, without demanding that they account for them. This amounted to $1.6 \%$ of total payments by the king. We don't know whether cost allowances covered actual costs, or whether they were merely used as a way to increase the rate of return. In our cash flows, we treat them in the same way as any other payment to the bankers. Hence, their effect is incorporated in the gross profitability figures. They typically amounted to $1-2 \%$ of the principal.

Finally, our rates of return are nominal. The second half of the sixteenth century saw the heyday of the price revolution, as inflows of American silver caused a general increase in the price level. Existing price indices are not accurate enough at yearly frequencies, preventing us from calculating real rates of return for each contract. Period averages are more reliable. Between 1556 and 1600 , prices rose by $80 \%$ - an annualized rate of $1.7 \%$ (Drelichman, 2005).

We are now in a position to calculate net rates of return. The starting point is our benchmark estimate of $15.5 \%$, which already takes into account the effect of the bankruptcies. We subtract the $7.14 \%$ opportunity cost, up to $1.5 \%$ in intermediation costs, up to $2 \%$ in other transaction costs, and $1.7 \%$ for inflation. This yields a net real rate of return of $3.16 \%$ in a high cost scenario. If intermediation or transaction costs for a specific contract were lower, net real rates of return could have been as high as $5 \%$. While stressing that these are rough estimates, we note that a) they remain positive, in line with our general results and b) they are relatively modest values considering the risky nature of short-term lending. ${ }^{45}$

\section{Discussion}

Short-term lending to the Castilian crown was profitable. While the bankruptcies caused substantial losses for some bankers in the short run, they were more than offset by high returns in normal times. Few banking families failed to earn the rate of return of juros; even fewer actually lost money.

When losses occurred, they were small in absolute terms. The families that did not perform well lent relatively little, and participated in the market only for short periods. The key to profitability was to invest heavily, and for the long haul. Timing mattered. The largest lender, the Spinola, realized a MIRR of $19.3 \%$ on over 16 million ducats of capital because they successfully reduced their exposure ahead of the two defaults in our dataset. ${ }^{46}$ Those with negative rates of return happened to lend immediately before the bankruptcies.

We do not account for reschedulings that took place in the normal course of business. 78 asientos - almost $20 \%$ of the total - recognized and restructured earlier obligations that the Crown had failed to meet. This affected 24 different families.

\footnotetext{
43 The standard language is that the king will pay the bankers for 'hasta lo que se acostumbra entre hombres de negocios.'

44 This would only be problematic for our results if the bankers systematically undercharged the king for these services. There is no evidence to suggest this.

45 We do not know to what extent bankers sold on the loans they issued. If they sold the loans on at lower rates of interest, their profits would have been higher still. In the absence of reliable information, we refrain from speculation.

${ }^{46}$ The Spinola seem to have correctly anticipated the 1575 default. Correspondence between family members shows they discussed its likelihood as early as January 1575, and made the determination to reduce their exposure. While they possessed a strong network of informants, it is unlikely that they were given privileged information in a systematic way. In fact, the decision to stop payments was not made until July 1575 at the earliest (Sanz Ayán, 2004 ).
} 
The average rescheduled amount was 108,946 ducats, almost half the loan value of an average asiento contract. Overall, 8.5 million ducats were rescheduled through different contracts, almost $10 \%$ of the total amount. ${ }^{47}$ The asiento clauses in the new contract do not specify which loans were being rescheduled. They simply mention that payments from earlier contracts had been missed. This makes it impossible to correct cash flows for missed payments directly. We can still be certain that missed payments on earlier contracts only had a small impact on the calculated rates of return. Using the MIRR-based results, it would take losses of almost $9 \%$ of total capital to reduce profits to zero. ${ }^{48}$ Because rescheduled amounts represent $10 \%$ of total loans, only outright repudiation of $90 \%$ of the missed payments could reduce returns to zero. This never occurred. In fact, the reschedulings emphasize the need to compensate bankers. Typically, the king would add all missed payments to the amounts due in the new contract. In many cases, additional interest was added to compensate bankers for the delay. As long as the later contract was fulfilled, overall profitability cannot have been reduced by much as a result of the reschedulings.

An additional safeguard is that we have calculated the profitability of bankers as if their loans to Philip II constituted their entire portfolio. While most of the banking families did not lend to other monarchs, they held a wide variety of assets in addition to asientos. These included juros, which offered reasonable returns throughout the sixteenth century, as well as interests in Genoese commercial partnerships. Furthermore, many bankers acted as intermediaries, pooling resources obtained on European fairs while risking little of their own capital. ${ }^{49}$ In the 1575 bankruptcy, when the king defaulted on 14.6 million ducats, only four bankers had more than 100,000 ducats of their own capital at risk. ${ }^{50}$ While our data do not allow us to estimate the composition of banker portfolios, it is safe to say that short-term sovereign lending was not the dominant component.

Ex-post rates reflect the profitability of bankers in one specific state of the world. After accounting for the two bankruptcies in the period covered by our data, bankers earned a gross return of $8.3 \%$ over the long-term bond rate. This, however, was not the only possible outcome. Would bankers have fared much worse under alternative and, potentially, equally plausible scenarios?

The rates of return in our 'repudiation' scenario provide one answer. Had the king failed to pay back a single ducat in both the 1575 and 1596 defaults, bankers would have either broken even relative to the long-term bond rate, or made marginal losses. This is an extremely pessimistic scenario, and it could be argued that full repudiation was never a realistic risk. Bankers created a complex incentive structure to ensure that the king would come back to the table. ${ }^{51} \mathrm{~A}$ different kind of risk nonetheless merits consideration. Instead of defaulting twice between 1566 and 1600, the king could have defaulted three, four or more times, each time settling for a fraction of his debts.

Speculating on when additional bankruptcies might have happened, or how severe they might have been, is beyond the scope of our work. Our calculations nonetheless allow for a simple thought experiment. According to our MIRR baseline results ('settlement scenario'), bankers earned excess returns over the long-term bond rate of $8.3 \%$. The difference between the promised and the 'settlement' returns is $4.2 \%$. This suggests that, if the two defaults that we observe were typical, the king could have defaulted an additional two times and settled on similar terms before the bankers would have failed to earn the long-term bond rate. $^{52}$

To what extent do our results reflect perceptions of profitability at the time? Neither bankers nor royal officials thought in net present value terms, nor did they have the mathematical skills to calculate the rate of return from complex cash flows. This is unlikely to have resulted in incorrect decision-making. First, to value a perpetuity one does not actually need complex math. When the discount rate equals the yearly interest, the present value of a perpetual bond equals its face value, and the bond sells at par. This was the case with the majority of juros in the market - bankers effectively used a discount rate equivalent to the juro rate. Second, the text of the contracts makes it clear that everyone involved understood compound interest (described as 'interest on interest'). The intellectual jump from compounding to discounting is very small. Finally, many complex assets were valued correctly long before the advent of modern finance. ${ }^{53}$ Ultimately, as long as bankers followed the principle that 'more and earlier is better', they would have made decisions that closely mirrored the ones implied by our measures of profitability.

\footnotetext{
${ }^{47}$ In at least one very important case, the rescheduled amounts did not come from a previous loan. The largest rescheduling was for 2.3 million ducats with the Fugger family, which originated from missed payments on a mercury provisioning contract from the Almadén mines. Once again, we take a conservative approach and consider all rescheduled amounts as resulting from previous asientos. For the contract with the Fugger - one of the very few that actually specifies the origin of the rescheduled funds - , see AGS, Contadurías Generales, Legajo 87, 'Marcos Fúcar y Juan y Jacome Fúcar hermanos. Asiento tomado con ellos en 22 de julio de 1582 sobre la paga y consignación de 905.665.459 que Su Majestad les debe a ellos y a los herederos de Aponal Fúcar y sobre un millón de ducados con que socorren a Su Majestad.'

${ }^{48}$ Using the profit index, losses would have to amount to 9.3\%. These are gross values. Estimating net required losses is difficult, as the bankers would have likely incurred lower costs if they did not fulfill part of a contract.

49 On the overall activities of Genoese bankers and their relationship with the business of lending to the Spanish crown in the sixteenth century see Doria (1978) and Felloni (1978).

${ }^{50}$ The bankers were Constantín Gentil, Lucián Centurión, Nicolao de Grimaldo, and the Spinola family (De Carlos Morales, 2008). To the extent that bankers paid less to their depositors than the $7.14 \%$ opportunity cost of capital that we assumed, their returns would have been even higher because they effectively leveraged their returns.

51 On this point, see Drelichman and Voth (2011).

${ }^{52}$ The profit index yields similar results.

53 See Moore and Juh (2006) for an example of correctly priced options before the development of the Black-Scholes formula.
} 


\section{Conclusion}

One important goal of financial history is to determine the rate of return on different assets. In the case of bonds, most of the available data are based on nominal rates of interest, as contracted between borrower and lender (Homer and Sylla, 2005). Since defaults, repudiations, and restructurings have been a constant feature of lending to sovereign borrowing, differences between ex-ante and ex-post rates can be large. Two detailed studies have derived actual returns to lenders for the period 1850-1983 (Lindert and Morton, 1989) and 1920-39 (Eichengreen and Portes, 1989). Lindert and Morton show that lending was profitable overall, earning average excess returns over British (or American) bonds of approximately $0.4 \%$. We derive actual rates of return for borrowing before 1800, using estimates of actual cash flows. Key features of cross-border lending uncovered by Lindert and Morton (1989) and Eichengreen and Portes (1989) were already present at the dawn of sovereign borrowing - lenders earned a positive rate of return on average. In addition, we show that almost every lender to the king of Spain turned a profit.

Contrary to the dominant view in both the historical and the serial defaults literature, lending to the Spanish Crown was not a hallmark of irrational behavior. After accounting for the effect of the defaults, the average rate of return on short-term lending was $15.5 \%$, more than twice the long-term bond rate. Our sensitivity analysis and robustness checks show that lending was profitable even under highly unfavorable assumptions. Calculating profitability by family shows that those engaged in a long-term lending relationship with the Crown earned more than their opportunity cost in virtually all cases.

Our study focuses on the 1575 and 1596 defaults. This is dictated by data limitations. These bankruptcies affected loans contracted under the 'Genoese system', rather than those inherited from the personal dealings of Charles V. The settlements were reached quickly when compared to the modern experience (Benjamin and Wright, 2009). With the exception of a single contract in 1597, rates of return remained broadly unchanged after each bankruptcy, suggesting that lenders viewed the defaults as largely anticipated events, and priced their loans accordingly. Short-term lending effectively acted as an insurance mechanism. In exchange for paying a premium in normal times, the king was able to reduce his outlays when his finances came under extraordinary pressure. The magnitude of these reductions was proportional to the severity of the liquidity crises.

Short-term loans and liquid long-term debt market formed an efficient issuance system for sovereign debt. Far from being a conduit for irrational behavior, these loans delivered substantial and largely stable profits to investors, while offering valuable insurance to the king. Spain built its empire with the strength of its resources - and on the ability to leverage them via powerful debt instruments.

\section{Acknowledgments}

We thank Maristella Botticini, Fernando Broner, Tim Leunig, Jean-Laurent Rosenthal, Peter Temin, and seminar participants at the LSE, Harvard, and the Utrecht Early Modern Finance Workshop for helpful comments. Marcos Agurto, Hans-Christian Boy, Diego Pereira-Garmendía, Germán Pupato, Javier Torres and Cristian Troncoso-Valverde provided excellent research assistance. Financial support from SHHRC, the UBC Hampton Fund, and the Ministry of Science and Innovation of Spain is gratefully acknowledged. All errors remain ours.

\section{Appendix A. Assumptions used in the reconstruction of asiento cash flows}

The most important assumptions are those related to the valuation of juros, which the lenders often accepted as payment. The contracts refer to these bonds either by their face value and rate, or by their annual payment and face value. Because juros were simple annuities (or perpetuities), this information is sufficient to characterize them. To maintain consistency, we used the actual cash flow generated by the bonds, and discounted it using a benchmark rate of one fourteenth (7.14\%). This choice of rate stems from the observation that juros that paid one fourteenth of their capital every year traded at par throughout the second half of the sixteenth century, and represented the vast majority of issues. When a perpetuity trades at par, the present value formula implies that the discount rate equals the annuity rate. Juros that paid $5 \%$ were used mostly as part of the settlements, and were more likely to trade at a discount (Toboso Sánchez, 1987).

We valuated the bonds using standard present value formulas. In the case of perpetual juros, we used the present value of the equivalent perpetuity. In the case of lifetime annuities, we used the early modern accounting convention that a lifetime was equivalent to 33 years. Since lifetime juros were relatively rare, modifying this assumption does not alter the results in any significant way. By definition, lifetime juros had a shorter maturity maturity than perpetual ones. The present value of a lifetime juro was therefore lower than that of a perpetual juro with the same face value and yield. We exploit this fact in coding the contract with the Maluenda brothers in the text.

In some instances, the contract allowed the banker to change the 'head' of a lifetime annuity. This meant that a bond could be purchased from a very old person and registered in the name of a much younger one, thus extending the period during which it would continue to pay interest. When this happened, we assumed that bonds were purchased from persons that were threefourths of the way into their lifetime. Once again, because of the relatively few instances in which this maneuver was used, modifying this assumption has little impact on the results. 
Not all juros were created equal. Annual payments on bonds were made directly from the revenue streams backing them. If a particular tax source failed to perform in any given year some bondholders would not be paid, and the king was under no obligation to compensate them. As a general rule, most bonds were fully and regularly serviced, and their prices were very close to par. A notable exception were the juros backed by the revenues of the Casa de la Contratación. Introduced as part of the 1561 settlement, these juros were supposed to be serviced with the proceeds from the $20 \%$ tax that the Casa de la Contratación assessed on shipments of private silver. Because the silver revenues were considered a royal prerogative, however, the king could issue direct payment orders against them. The abuse of this practice left the Casa de la Contratación almost immediately unable to service the bonds it issued, and at the same time underscored the rationale for the requirement that juro issues only be authorized on revenues controlled by the Cortes. ${ }^{54}$ The juros de contratación traded at deep discounts between their introduction and the 1577 general settlement, when they were retired. Many asientos, however, allowed bankers to discharge obligations using contratación bonds at par, or to exchange them for other bonds with the same face value without penalty. This created an immediate profit opportunity not available to common bondholders. To estimate these gains we follow the evidence in De Carlos Morales (2008), which shows that juros de contratación traded at 50\% of their face value.

A second set of assumptions was needed to determine the dates in which certain payments were expected to take place. Most disbursements and repayments were stipulated on specific dates, or at fairs with well-known time frames. In the few instances when the month in which a fair took place cannot be determined with precision, we made educated guesses based on information about the fairs immediately preceding and following it. In some cases, as in the contract with the Maluenda brothers, the time of payment was tied to the arrival of the silver fleets, which was subject to mining production and weather events. The contracts were signed without knowing when (or if) the fleets would arrive. Morineau (1985) reports the actual arrival dates for most fleets after 1584 . Their median arrival month was September, with over $80 \%$ of them arriving between July and November. Since the contracts specified that payments would take place one month after the fleet's arrival, we entered the cash flows tied to the fleet's arrival as being expected in the month of October. Most contracts specified an additional 1\% monthly interest should the fleet arrive late, and a $1 \%$ monthly discount should it be early. This allowed the king to match his revenues to his outlays, while introducing little variation in the overall profitability of the contract if the deviations from the expected arrival times were small.

\section{Appendix B. Notes on the modified internal rate of return}

While very useful in establishing the rate of return of complex cash flows, the MIRR requires the exogenous specification of two discount rates. The obvious choice for a reinvestment rate is the juro yield of $7.14 \%$. Juros were relatively safe investments that could be traded on a fairly liquid market. Any banker with the financial wherewithal to lend to Philip II could certainly secure a long-term bond at par if he found himself with any excess cash. Many bankers were able to do better with their funds, as their continued participation in lucrative asientos shows. The more active families also scoured the secondary juro market for bonds that were not performing well, purchasing them at a discount and using their connections to redeem them at par. The standard juro rate, therefore, is a safe lower bound for the reinvestment rate.

Specifying the finance rate is trickier. Despite misleading technical notes to the contrary in financial software and trade publications, the finance rate is not an interest rate paid on borrowed funds, but rather a discount rate used to measure the opportunity cost of negative flows. Intuitively, the MIRR formula assumes that the lender has to gather the present value of all disbursements at time zero. Whatever is not immediately disbursed is placed in a savings account, where it earns the finance rate. This enables the lender to exactly meet the required disbursements as they come due. This formulation has the desirable property that deferring disbursements increases the project's rate of return. The first derivative of the formula with respect to the finance rate is positive. Specifying a higher finance rate will, ceteris paribus, increase the overall rate of return for the project. The lowest logical rate of return will hence result from specifying a finance rate equal to zero. ${ }^{55}$

Common practice holds that the finance rate used to valuate a project should be the interest cost incurred on borrowed funds. The definition of the MIRR, however, does not lend any logical support to this practice. Bankers with access to the funds required by a project in advance could very well earn the reinvestment rate until the disbursements came due. We will bias the results against finding profitability by specifying the finance rate at $5 \%$ for our benchmark estimates. This was the lowest yield of any juro that was not part of a forced conversion, and clearly below the average yield of long-term debt. We also conduct sensitivity analysis by lowering the finance rate all the way to zero. Since intermediate negative cash flows are substantially smaller than intermediate positive ones, the impact of any finance rate assumption will be limited.

\footnotetext{
${ }^{54}$ A detailed analysis of this episode can be found in Ruiz Martín (1965). See also De Carlos Morales (2008).

${ }^{55}$ While the MIRR formula allows for negative finance rates, it would not be rational for an investor to borrow unneeded funds and pay interest on them until they are disbursed.
} 


\section{Appendix C. Additional profit index results}

Table $\mathrm{C} 1$ reports the weighted average profit index for all contracts using five different discount rate assumptions. Its results closely track those obtained using the MIRR (reported in Table 5 in the main text).

Table C1

Profit index (all contracts, 1566-1600, annualized rates).

\begin{tabular}{lllr}
\hline Discount rate & Original agreement & Settlements & Repudiation \\
\hline $0.00 \%$ & $34.4 \%$ & $18.6 \%$ & $8.2 \%$ \\
$5.00 \%$ & $25.3 \%$ & $11.7 \%$ & $2.7 \%$ \\
$\mathbf{7 . 1 4 \%}$ & $\mathbf{2 2 . 1 \%}$ & $\mathbf{9 . 2} \%$ & $\mathbf{0 . 7 \%}$ \\
$10.00 \%$ & $18.3 \%$ & $6.2 \%$ & $-1.7 \%$ \\
$17.19 \%$ & $10.5 \%$ & $0.0 \%$ & $-6.7 \%$ \\
\hline
\end{tabular}

The profit index also suggests an alternative way of measuring the overall returns to short-term lending. Instead of calculating a weighted average of the rate of return of each contract, we aggregate the cash flows into a single project running from 1566 to $1600 .{ }^{56}$ This effectively treats the collective of bankers as a single financial entity, whose rate of return we now calculate. We still use the undiscounted sum of all disbursements as our measure of capital at risk. Since most disbursements were more than offset by repayments within a few months or years, this grossly exaggerates capital at risk, and hence underestimates actual returns.

Table C2

Profit index (aggregate cash flows, 1566-1600, annualized rates).

\begin{tabular}{lccc}
\hline Discount rate & Original agreement & Settlements & Repudiation \\
\hline $0.00 \%$ & $35.2 \%$ & $19.1 \%$ & $8.6 \%$ \\
$5.00 \%$ & $13.6 \%$ & $6.11 \%$ & $2.2 \%$ \\
$\mathbf{7 . 1 4 \%}$ & $\mathbf{9 . 5 \%}$ & $\mathbf{3 . 8 \%}$ & $\mathbf{1 . 0 \%}$ \\
$10.00 \%$ & $6.0 \%$ & $1.8 \%$ & $0.0 \%$ \\
$15.55 \%$ & $2.4 \%$ & $0.0 \%$ & $-1.0 \%$ \\
\hline
\end{tabular}

Table C2 shows that, calculated this way, lending to Philip II would have been profitable with discount rates up to $15.5 \%$. This is a remarkable result. The overall returns to sovereign lending remain positive even under the enormous weight of using an already inflated measure of capital at risk and leaving it undiscounted over a 34-year period.

\section{References}

Alvarez Nogal, Carlos, 2003. The role of institutions to solve sovereign debt problems: The spanish monarchy's credit (1516-1665). Universidad Carlos III working paper 03-08.

Arellano, C., 2008. Default risk and income fluctuations in emerging economies. The American Economic Review 98 (3), $690-712$.

Artola, Miguel, 1982. La hacienda del antiguo régimen. Alianza, Madrid.

Baker, M., Wurgler, J., 2007. Investor sentiment in the stock market. The Journal of Economic Perspectives 21 (2), $129-151$.

Barberis, N., Shleifer, A., Vishny, R., 1998. A model of investor sentiment. Journal of Financial Economics 49 (3), $307-343$.

Bénabou, Roland, 2009. “Groupthink: Collective Delusions in Organizations and Markets.” NBER Working Paper 14764.

Benjamin, David, Wright, Mark, 2009. Recovery before redemption: a theory of delays in sovereign debt renegotiations. UCLA working paper.

Berger, Allen N., Udell, Gregory F., 1995. Relationship lending and lines of credit in small firm finance. Journal of Business 68 (3), $351-381$.

Braudel, Fernand, 1966. The Mediterranean and the Mediterranean world in the age of Philip II. Second Revised Edition. William Collins \& Sons, Glasgow.

Bulow, Jeremy, Rogoff, Kenneth, 1989. A constant recontracting model of sovereign debt. Journal of Political Economy 97 (1), $155-178$.

Carande, Ramón, 1987. Carlos V y sus banqueros. 3. ed. 3 vols. Crítica, Barcelona.

Carretero Zamora, Juan Manuel, 1988. Cortes, monarquía, ciudades. Las Cortes de Castilla a comienzos de la época moderna (1476-1515). Siglo XXI, Madrid.

Conklin, James, 1998. The theory of sovereign debt and Spain under Philip II. Journal of Political Economy 106 (3), $483-513$.

De Carlos Morales, Carlos Javier, 2008. Felipe II: El Imperio en Bancarrota. Dilema, Madrid.

Doria, Giorgio, 1978. Conoscenza del mercato e sistema informativo: il know-how dei mercanti-finanzieri genovesi nei secoli xVI e XVII. In: Otazu, A. (Ed.), Dinero y Crédito (siglos XVI al XIX). Actas del Primer Coloquio Internacional de Historia Económica. Madrid.

Drelichman, Mauricio, 2005. The curse of Moctezuma: American silver and the Dutch disease. Explorations in Economic History 42 (3), 349-380.

Drelichman, Mauricio, and Voth, Hans-Joachim, 2010. The Sustainable Debts of Philip II: A Reconstruction of Castile's Fiscal Position, 1566-1596. The Journal of Economic History 70 (4): 813-832.

Drelichman, Mauricio, Voth, Hans-Joachim, 2011. Lending to the borrower from hell: debt and default in the age of Philip II. The Economic Journal, forthcoming. Eaton, Jonathan, Fernandez, Raquel, 1995. Sovereign debt. NBER Working Paper Series.

Eaton, Jonathan, Gersovitz, Mark, 1981. Debt with potential repudiation: theoretical and empirical analysis. Review of Economic Studies 48 (2), $289-309$.

Eichengreen, Barry, Portes, Richard, 1989. After the deluge: default, negotiation and readjustment of foreign loans during the interwar year. In: Eichengreen, B., Lindert, P. (Eds.), The International Debt Crisis in Historical Perspective. MIT Press, Cambridge, MA.

56 The MIRR is ill-suited for this type of exercise, as it assumes that intermediate positive cash flows continue to earn the reinvestment rate until the end of the project. A positive cash flow in 1566, for example, would be assumed to earn the reinvestment rate all the way until 1600 . Since by the very nature of lending the absolute value of positive cash flows exceeds that of negative ones, this causes the MIRR to converge to the reinvestment rate in the long run. 
Felloni, Giuseppe, 1978. Asientos, juros y ferias de cambio desde el observatorio genovés (1541-1675). In: Otazu, A. (Ed.), Dinero y Crédito (siglos XVI al XIX). Actas del Primer Coloquio Internacional de Historia Económica. Madrid.

Fortea Pérez, José Ignacio, 2009. Las Cortes de Castilla y León bajo los Austrias: una interpretación. Junta de Castilla y León.

Gelabert, Juan, 1999. Castile, 1504-1808. In: Bonney, R. (Ed.), The Rise of the Fiscal State in Europe, c. 1200-1815. Oxford University Press, Oxford.

Grossman, Herschel I., Van Huyck, John B., 1988. Sovereign debt as a contingent claim: excusable default, repudiation, and reputation. The American Economic Review 78, 1088-1097.

Guerrieri, Veronica, Kondor, Peter, 2010. Fund Managers, Career Concerns, and Asset Price Volatility. Chicago GSB Working Paper.

Homer, Sydney, Sylla, Richard, 2005. A history of interest rates, Fourth ed. John Wiley \& Sons, Hoboken.

Jago, C., 1981. Habsburg absolutism and the Cortes-of-Castile. The American Historical Review 86 (2), $307-326$.

Jago, Charles, 1985. Philip II and the Cortes of Castile: The Case of the Cortes of 1576. Past and Present 109, 22-43.

Kohlscheen, E.W., 2007. Why are there Serial Defaulters? Evidence from Constitutions. Journal of Law and Economics 50, 713-730.

Kovrijnykh, Natalia, Szentes, Balázs, 2007. Equilibrium default cycles. Journal of Political Economy 115 (3), $403-446$.

Las Cortes de Castilla y León en la Edad Moderna. 1989. Valladolid: Cortes de Castilla y León.

Lindert, Peter, Morton, P.J., 1989. How sovereign debt has worked. In: Sachs, J. (Ed.), Developing country debt and economic performance. Chicago University Press, Chicago.

Lovett, A.W., 1980. The Castilian Bankruptcy of 1575. The Historical Journal 23, 899-911.

Lovett, A.W., 1982. The general settlement of 1577: an aspect of Spanish finance in the early modern period. The Historical Journal 25 (1), 1-22.

Marcos Martín, Alberto, 2000. España en los siglos XVI, XVII y XVIII : economía y sociedad. Crítica, Barcelona.

Mitchener, Kris James, Weidenmier, Marc D., 2010. Supersanctions and sovereign debt repayment. Journal of International Money and Finance.

Moore, Lyndon, Juh, Steve, 2006. “Derivative Pricing 60 Years before Black-Scholes: Evidence from the Johannesburg Stock Exchange”. Journal of Finance 61 (6), 3069-3098.

Morineau, Michel, 1985. Incroyables gazettes et fabuleux metaux. Cambridge University Press, London.

Munro, John H., 2004. Money and Coinage: Western Europe. In: Dewald, J. (Ed.), The dictionary of early modern Europe: 1450-1789. Charles Scribner's Sons/The Gale Group, New York.

Parker, Geoffrey, 1998. The Grand Strategy of Philip II. Yale University Press, New Haven.

Petersen, Mitchell A., Rajan, Raghuram G., 1994. The benefits of lending relationships: evidence from small business data. Journal of Finance 49 (1), 3-37.

Petersen, Mitchell A., Rajan, Raghuram G., 1995. The effect of credit market competition on lending relationships. Quarterly Journal of Economics 110 (2), 407-443.

Reinhart, Carmen M., Rogoff, Kenneth, 2009. This time is different: eight centuries of financial folly. Princeton University Press, Princeton.

Reinhart, Carmen, Rogoff, Kenneth, Savastano, Miguel, 2003. Debt intolerance. Brookings Papers on Economic Activity 1.

Ruiz Martín, Felipe, 1965. Un expediente financiero entre 1560 y 1575. La hacienda de Felipe II y la Casa de Contratación de Sevilla. Moneda y Crédito 92, 3-58.

Sanz Ayán, Carmen, 2004. Estado, monarquía y finanzas. Estudios de historia financiera en tiempos de los Austrias. Centro de estudios políticos y constitucionales, Madrid.

Temin, Peter, Voth, Hans-Joachim, 2006. Banking as an emerging technology: Hoare's bank, 1702-1742. Financial History Review 13 (2), $149-178$.

Thompson, I.A.A., 1976. War and government in Habsburg Spain. The Athlone Press - University of London, London.

Thompson, I.A.A., 1993. Crown and Cortes. Government, Institutions and Representation in Early-Modern Castile. Variorum, Aldershot.

Thompson, I.A.A., 1994a. Castile: absolutism, constitutionalism, and liberty. In: Hoffman, P.T., Norberg, K. (Eds.), Fiscal crises, liberty, and representative government, 1450-1789. Stanford University Press, Stanford, pp. 180-225.

Thompson, I.A.A., 1994b. Castile: polity, fiscality, and fiscal crisis. In: Hoffman, P.T., Norberg, K. (Eds.), Fiscal crises, liberty, and representative government, 14501789. Stanford University Press, Stanford, pp. 140-180.

Toboso Sánchez, Pilar, 1987. La deuda pública castellana durante el Antiguo Régimen (juros) y su liquidación en el siglo XIX. Instituto de Estudios Fiscales, Madrid. Tomz, Michael, 2007. Reputation and international cooperation: sovereign debt across three centuries. Princeton University Press, Princeton.

Torres López, Manuel, and Pérez-Prendes, J.M., 1963. Los Juros (aportación documental para una historia de la deuda pública en España). Fábrica de Moneda y Timbre.

Ulloa, Modesto, 1977. La hacienda real de Castilla en el reinado de Felipe II2. ed. Fundación Universitaria Española, Seminario Cisneros, Madrid.

Wallich, H.C., 1943. The future of Latin American dollar bonds. The American Economic Review 33 (2), $321-335$.

Yue, Vivian, 2010. Sovereign default and debt renegotiation. Journal of International Economics 80 (2), 176-187.

Yun Casalilla, Bartolomé, 2002. El Siglo de la Hegemonía Castellana (1450-1590). In: Comín, F., Hernández, M., Llopis, E. (Eds.), Historia Económica de España, Siglos X-XX. Crítica, Barcelona.

Yun Casalilla, Bartolomé, 2004. Marte contra Minerva. El precio del imperio español, c. 1450-1600. Crítica, Barcelona. 